\title{
CORRELATES OF PROCUREMENT PERFORMANCE OF TRADITIONAL AND LABOUR-ONLY METHODS IN NIGERIA \\ OGUNSANMI, O.E. \\ http://dx.doi.org/10.4314/ejesm.v6i2.9
}

Received 3rd January 2012; accepted 22nd February 2013

\begin{abstract}
Correlates of procurement performance of Traditional and Labour- only methods are investigated. Purpose of this study is to investigate if procurement challenges, contractual procedures, designer's experience, building type and final contract sum have influences on the performance of both methods. 120 questionnaires were sent out to the various respondents who have used the two methods. 64 responses were received from 39 Traditional projects and 25 Labour-only projects. Results indicate that unit cost of Labour-only correlates significantly with all procurement challenges. Unit cost of Traditional procurement also correlates significantly with lack of adequate supervision while build time and total time both demonstrate significant relationships with most challenges. Labour-only performance factors demonstrate no significant correlation with contractual procedure, designer's experience; build type and final contract sum. Traditional performance factors demonstrate no significant correlation with contractual procedures and designer's experience while it demonstrates significant correlations with building type and final contract sum. Study concludes that procurement challenges in both methods affect their unit cost, build time and total time and may be expensive to use both methods. Performances of both methods do not depend on contractual procedure, and designer's experience but that of Traditional method can be influenced by building type and final contract sum. Study recommends that consultants, clients and stakeholders should ensure that all challenges are well managed to avoid cost escalations. For better performance of future projects unit cost should be kept low while cost and time overruns must be avoided.
\end{abstract}

Keywords: Correlates, Procurement performance, Traditional, Labour-only, Nigeria

\section{Introduction}

Most clients, stakeholders and construction practitioners are fully aware of the concept of construction procurement but are not too informed of procurement performance. Construction procurement is defined as the process of acquiring a facility by directly buying, leasing or designing and constructing the facility to meet specific need. Once the procured facilities are in use much is forgotten about the procurement process and performance of this method that generates this facility. Procurement performance has been a point of concern to many researchers all over the world. Various studies noted in this direction are Naoum (1991), Pinto and Slevin (1998), McDermont, (1999), Holt and Graves (2001), Ogunsanmi, Iyagba and Omirin (2001), Alarcon and Serpell (2004), Ojo (2009), Public
Procurement Audit Seminar (2010), and Abdolalipour, Shafiee and Razaiee (2011). These studies discussed various dimensions of procurement performance but recent studies emanating from works of Holt and Graves (2001) considers benchmarking as a non financial assessment that measures performance improvements in public procurement. This study advocates for feasible measures for assessing projects at strategic levels of procurement. Alarcon and Serpell (2004) draw on performance model for benchmarking. This study involves designing and implementing project performance measurement systems for construction companies in Chile with the aim of improving company's performance. In Nigeria the study of Ojo (2009) examines the performance indices for different procurement methods in use in Nigeria against their selection 
criteria. Study of Dada (2012) is on Traditional procurement and it indicates that the method has been long used for both public and private projects. It further considers the perceptions of stakeholders on issues of Traditional procurement. Experience of the designer, the contractual procedures used as well as encountered project related problems can influence performance of such projects. There have been very few studies on procurement performance that have discussed the relationship of designer's experience, contractual procedures and procurement related problems with procurement performance. This present study discusses such relationships and it also investigates if the designer's previous experience, the contractual procedures in use as well as procurement related problems could have influences on procurement performance of Traditional and Labour-only methods in Nigeria. The aim of the study is to determine correlates of procurement performance of Traditional and Labour- only methods. The purpose of this study is to investigate if designer's experience, contractual procedures used as well as project related problems have relationship with the performances of both procurements. This study is significant in a number of ways as it provides an insight into the types of procurement methods in use in construction in Nigeria and it also highlights the correlates of procurement performance. It also enables stakeholders, clients, contractors and consultants to be aware of procurement performance for their future project endeavours in Nigeria and other developing countries. The study contributes to Literature in procurement performance for the academia and for the society at large using procurement strategies for their project delivery.

\section{Construction Procurement Strategies in Use}

There are various procurement methods in use in construction for project delivery in Nigeria. Such strategies include Traditional, Design and Build, Project Management, Direct Labour and Labour-only. Studies of Ogunsanmi, Iyagba and Omirin (2001), Ibiyemi, Adenuga and Odusami (2005), Babatunde, Opawole and Ujaddigbe (2010) and Dada (2012) have all confirmed the use of these methods in Nigeria. Similarly, studies of
Rowlinson (1987), Naoum and Langford (1987), Grierson (1988), Franks (1990), Bennett (1992), Hutchinson and Putt (1992) as cited in Ogunsanmi, (2001) also confirm the use of these methods for project delivery elsewhere in the World. Most projects in Nigeria have been procured through the use of Traditional procurement while Labour-only procurement has recently been used for project execution. These two methods are now compared for performances for which correlates of their performances are now investigated in this study.

\section{Traditional Procurement Method}

Construction management literature has confirmed the dominancy of the Traditional procurement method for housing delivery. When this method is used by a client who desires a building or a facility he appoints consultants for design and cost control functions. These consultants assist the client to select a contractor who executes the project. The contractor works for a contract price. Importantly, design and construction responsibilities are separated and this results in drawbacks of Traditional procurement for which time and cost overruns and conflicts between parties are predominant. Traditional procurement types in use include sequential and accelerated methods. Most projects in Nigeria, Great Britain, and other Commonwealth countries all over the World are procured using Traditional procurement.

\section{Labour-Only Procurement Method}

In Nigeria because of the recent downturn in the economy of the country most practitioners prefer to use Labour-only method for project delivery than Traditional method that has stood the test of time. This method has found more patronage not only in Nigeria but also in some sub-Saharan countries of Uganda, Zimbabwe, Botswana, Kenya and South Africa where the method has been used for delivering several community based projects. Studies of Ogunsanmi, Iyagba and Omirin, (2003); Babatunde, Opawole and Ujaddugbe, (2010); Samatania Consult Limited, (2012); and Dada (2012) all confirm the use of this method in Nigeria. 


\section{Measures of Construction Procurement Performance}

Construction procurement performance has been a major point of attraction to some researchers all over the World. Such efforts are documented in studies of Rowlinson and Newcombe (1986), Naoum and Langford (1987), Naoum (1991), Pinto and Slevin (1988), Masterman (1992), Alarcon and Ashley (1996), McDermott (1999), and Ogunsanmi, Iyagba and Omirin (2001). Most of these earlier studies modeled procurement process except for study of Ogunsanmi, Iyagba and Omirin (2001) that modeled procurement performance. Recent studies of Holt and Graves (2001), Alarcon and Serpell (2004), Ojo (2009), Public Procurement Audit Seminar (2010) and Abdolalipour, Shafiee and Rezaiee (2011) documented various dimensions of procurement performance. Holt and Graves (2001) developed a benchmark modeling for procurement performance, Alarcon and Serpell (2004) developed computer models for measuring the performance of some construction companies in Chile, Ojo (2009) developed some performance indices for different procurement methods in Nigeria, Public Procurement Audit Seminar (2010) evolved a procurement performance model for assessing performance of procured public projects while Abdolalipour, Shafiee and Rezaiee (2011) employed a balance scorecard for measuring procurement performance. All these previous studies are relevant to this work as issues of procurement performance measures can be drawn from these studies. One area of commonality of all these research works has been the research variables used in measuring procurement performance. Model of Rowlinson and Newcombe (1986) measured performance as ratios of contracted to actual time and cost, client satisfaction with time and cost. Naoum (1987) in his theoretical model for comparing project performance measured performance in terms of time, cost and quality. Theoretical model of project success by Pinto and Slevin (1988) documented procurement performance in terms of time, cost, performance, use, satisfaction and effectiveness. Cost, schedule, value and effectiveness are the performance measures used by Alarcon and Ashley (1996) in their general performance model (GPM). Furthermore, Naoum (1991) building process model measured performance in terms of time, cost, overruns of time and cost, client satisfaction with cost and quality of project. Ogunsanmi, Iyagba and Omirin (2001) measured procurement performance using time (pre-construction time, build time, and total project time), speed of construction, unit cost, overruns of time and cost, client satisfaction with time, cost and quality, user's satisfaction with project effectiveness and client satisfaction with the use of completed project to date. Measures of procurement performance used over the years as reviewed in works of other researchers include cost, time, and satisfaction with time, cost, quality and effectiveness. Such measures of procurement performance are explored in this study when the two notable procurement methods in use in housing projects in Nigeria were compared for procurement performance using these identified variables of performance.

\section{Methodology}

Literature review was undertaken to identify procurement performance factors as well as challenges faced by the two procurement methods. 34 hypothesized procurement performance variables were derived from this review and used for this study. Four types of questionnaires were designed and validated in a pilot study to collect the primary data from clients, users of project, consultants and contractors who constitute the population of the study. This study covers states of Lagos, Kwara, Oyo, Ogun, Anambra, Enugu, Delta, Borno, Rivers, Abia, and Abuja the Federal capital Territory in Nigeria. Sample for the study was selected using systematic random sampling technique. In all, 120 questionnaires were sent out to the various respondents in which 64 responses were obtained from 39 Traditional procurement projects and 25 Labour-only projects. Statistical tools employed for the analysis include tables, percentages and correlation for drawing inferences on possible relationships between the variables of the study. 
Result and Discussion

Relationship between Procurement Challenges and Performance factors of Labour-only procurement

Results in Table 1 indicate that unit cost correlates positively with all procurement challenges factors except no team relationship. Most of the relationships of procurement challenges with unit cost show significant correlations. Pre-construction time demonstrates negative relationships with conflict on project, inefficient coordination and planning, lack of control, and lack of adequate supervision on project. It also demonstrates positive relationships with no team relationship and lack of communication on projects. None of these correlations are significant. Build time shows negative relationships with conflict on project, ineffective coordination, lack of control, no team relationship and lack of adequate supervision on project. It also demonstrates positive relationships with ineffective planning and lack of communication on projects but none of these correlations are significant. Also in Table 1, it is indicated that total time correlates negatively with conflict on project, ineffective planning, lack of control, no team relationship and lack of adequate supervision.

Table 1 Correlations of procurement challenges with performance factors of Labour-only Procurement

\begin{tabular}{|c|c|c|c|c|c|c|c|}
\hline $\begin{array}{l}\text { Variable } \\
\text { Challenge } \\
\text { Loc Perf }\end{array}$ & $\begin{array}{l}\text { Conflict } \\
\text { on Project }\end{array}$ & $\begin{array}{l}\text { Ineff. } \\
\text { Co-ord. }\end{array}$ & $\begin{array}{l}\text { Ineff. } \\
\text { Planng }\end{array}$ & $\begin{array}{l}\text { Lack of } \\
\text { Control }\end{array}$ & $\begin{array}{l}\text { No } \\
\text { Team } \\
\text { Rela. }\end{array}$ & $\begin{array}{l}\text { Lack of } \\
\text { Adeq. } \\
\text { Super }\end{array}$ & $\begin{array}{l}\text { Lack } \\
\text { Comm } \\
\text {. }\end{array}$ \\
\hline Unit cost & $.5107 *$ & $.5109 *$ & $.5051 *$ & $.5736^{*}$ & .4766 & $.5371^{*}$ & $.7835^{*}$ \\
\hline Pre-const & -.2350 & -.2107 & -.1904 & -2362 & .2808 & -.2004 & 0.4206 \\
\hline B. Time & -.2109 & -.0980 & .1165 & -.1534 & -.2396 & -.0634 & .3492 \\
\hline T.Time & -.2973 & .2525 & -.1503 & -.2902 & -.3397 & -.1629 & .4271 \\
\hline Speed & -.2230 & -.1157 & -.1879 & -.1540 & -.2210 & -.2276 & .6376 \\
\hline $\begin{array}{l}\text { Qua. Satis. } \\
\text { Proj. Use. }\end{array}$ & -.9083 & .2316 & .1209 & -0616 & -.0656 & -.2003 & .1667 \\
\hline Sat. & -.1296 & -.4178 & -.3384 & -.5419 & -.1442 & -.3264 & .7083 \\
\hline $\begin{array}{l}\text { C. Over. } \\
\text { Time }\end{array}$ & .1905 & .1203 & .1854 & .1649 & 1999 & .1429 & -.1643 \\
\hline Overrun & -.2127 & -.2307 & .2183 & -.2091 & -.1869 & -.0547 & -.4867 \\
\hline
\end{tabular}

1 tailed significant $* 0.01 * *-0.001$.

It correlates positively with ineffective coordination and lack of communication. None of these correlations are significant. Speed of construction correlates negatively with ineffective coordination, ineffective planning, lack of control, no team relationship and lack of adequate supervision. It correlates positively with conflict on project and lack of communication but none of these correlations are significant.

From the results in Table 1 it is further shown that satisfaction with quality on project demonstrates negative relationship with conflict on project, lack of control, no team relationship and lack of adequate supervision on project. It also demonstrates positive relationship with ineffective coordination and planning as well lack of communication on project. None of these correlations are significant. Satisfaction with use of project to date also shows negative relationships with conflict on project, ineffective coordination and planning, lack of control and supervision and no team relationship. It also demonstrates positive relationship with lack of communication. Similarly, none of these relationships with the procurement factors are significant.

Cost overrun show positive relationships with conflict on project, ineffective coordination and planning, lack of control and 
supervision and no team relationship. It also demonstrates negative relationship with lack of communication but none of these correlations are also significant. Time overrun show negative relationships with conflict on project, ineffective coordination, lack of control and adequate supervision, no team relationship, and lack of communication. It also demonstrates positive relationship with ineffective planning but none of these correlations are significant. In all these relationships discussed between procurement challenges and performance factors of Labour-only procurement only significant relationships are observed for unit cost with all the procurement problems. Hence, this significant relationship supports the alternative hypothesis and hence it is accepted. This implies that as Labour-only procurement challenges become more complex and deepened the unit cost of such projects escalates. It may be very expensive to achieve Labour-only projects if these procurement problems are highly pronounced on a project.

\section{Relationship between Procurement Challenges and Performance factors of Traditional procurement}

Table 2 also indicates that unit cost show negative relationships with ineffective coordination and planning, lack of control and communication and no team relationship. It also demonstrates positive relationships with conflict on project and lack of adequate supervision on project. Positive relationship of unit cost with lack of adequate supervision is significant at 0.01 significance levels. This involves accepting the alternative hypothesis. This hence infers that significant relationship exists between unit cost and lack of adequate supervision. Table 2 shows that speed of construction has negative relationship with conflict on project and positive relationships with ineffective coordination and planning, lack of control, communication and adequate supervision as well as no team relationship. None of these correlations are significant. Cost overrun has negative relationships with all the procurement challenges in Traditional procurement. None of these correlations are also significant. Time overrun shows positive relationships with conflict on project, ineffective coordination and planning, no team relationship and lack of communication and adequate supervision. It also demonstrates negative relationship with lack of control on project. Similarly, none of these correlations are significant. Pre-construction time shows negative relationships with conflict on project, ineffective planning, and lack of control, communication and adequate supervision as well as no team relationship. It demonstrates positive relationship with ineffective coordination. None of these relationships are significant. Build time in Traditional project show negative significant relationships with all the procurement challenges faced in this method. This quickly suggests that build time on Traditional projects can significantly increase with less pronounced challenges facing the project. This is an unexpected result as build time supposes to reduce with less pronounced challenges facing the project. For the significant relationships the alternative hypothesis is accepted. Procurement challenges are significantly related to build time of Traditional procurement.

Total time in Traditional procurement also show negative significant relationships with all the procurement challenges. This also indicates that total time can increase significantly with less pronounced challenges facing the project. This result is also unexpected as total time supposes to reduce with less pronounced challenges facing the project. For these significant relationships the alternative hypothesis is also accepted. Procurement challenges are significantly related to total time of Traditional procurement. Satisfaction with quality on project demonstrates positive relationships with all the procurement challenges. Satisfaction with project use to date shows positive relationships with all the procurement challenges facing Traditional projects but none of these correlations are significant. In all these discussed relationships significant relationships are observed for unit cost, build time and total time with all the procurement problems. This supports the alternative hypothesis and it is accepted.

This infers that procurement challenges have strong association with unit cost, build time and total time of Traditional procurement. As challenges become more complex and 
deepened the unit cost of such projects escalates while build time and total time are significantly reduced. It may be very expensive to build Traditional projects.

Table 2 Correlations of procurement challenges and performance of Traditional procurement

\begin{tabular}{|c|c|c|c|c|c|c|c|}
\hline $\begin{array}{l}\text { Variable } \\
\text { Challenge } \\
\text { Tra Perfoma }\end{array}$ & $\begin{array}{l}\text { Conflict } \\
\text { in Project }\end{array}$ & $\begin{array}{l}\text { Ineffec. } \\
\text { Co-ord. }\end{array}$ & $\begin{array}{l}\text { Ineffec. } \\
\text { Planng }\end{array}$ & $\begin{array}{l}\text { Lack of } \\
\text { Control }\end{array}$ & $\begin{array}{l}\text { No } \\
\text { team } \\
\text { Relatio } \\
\text { nship }\end{array}$ & $\begin{array}{l}\text { Lack of } \\
\text { Comm. }\end{array}$ & $\begin{array}{l}\text { Lack of } \\
\text { Adeq. } \\
\text { Super } \\
\text { vision }\end{array}$ \\
\hline Unit cost & 0.0135 & -.2636 & -.3121 & -.2791 & -.3038 & -.2625 & $.7538 *$ \\
\hline Speed & -.1876 & .1881 & .2501 & .3398 & .1958 & .2450 & .2109 \\
\hline Cost overrun & -.4536 & -.4502 & -.4457 & -.3877 & -.4363 & -.4128 & -.4661 \\
\hline Time overrun & .0565 & .1345 & .1217 & -.1263 & .1872 & .1195 & .0873 \\
\hline Pre-con. Time & -.3725 & .5460 & -.5032 & -.4164 & -.5255 & -.4796 & -.5729 \\
\hline Build time & -.3591 & $-.7123 *$ & $-.5868^{*}$ & $-.6693^{*}$ & $-.6591^{*}$ & $-.6435^{*}$ & $-.7059 *$ \\
\hline Total time & -.2883 & $-.6426^{*}$ & -.5230 & -.5316 & $-.5952^{*}$ & -.5590 & $.6442 *$ \\
\hline $\begin{array}{l}\text { Quality } \\
\text { satisfaction }\end{array}$ & .1625 & 2207 & .2207 & .1064 & .3369 & .2880 & .1796 \\
\hline $\begin{array}{l}\text { Proj. Use } \\
\text { Satisfaction }\end{array}$ & .1231 & .1584 & .1584 & .0537 & .3697 & .4364 & .2041 \\
\hline
\end{tabular}

1 tailed significance $*_{-} 0.01 *^{*} *_{-} .001$

Relationship between Contractual procedures, Designer's experience, building type, Final contract sum and Performance factors of Labour-only procurement

In Table 3 it is revealed that correlations exist between contractual procedures and Labour-only performance factors. None of these correlations are significant hence they all support the null hypothesis and hence it is accepted. This implies that no association between contractual procedures used and performance factors of Labour-only procurement. Irrespective of the contractual methods and procedures in use in Labour-only procurement the performance of the method does not strongly dependent on contractual procedure used.

Furthermore, it is revealed in Table 3 that correlations exist between Designer's experience and performance factors of Labouronly procurement. Some of these correlations are generally low while variables like preconstruction time, build time, total time, speed, satisfaction on quality as well as time overrun show negative relationships with Designer's experience while other variables demonstrate positive relationships. None of these correlations are significant and hence they all support the null hypothesis. The null hypothesis is also accepted. Designer's experience has no strong association with performance of Labour-only procurement. Irrespective of the experience that Designers bring into Labour-only design such experiences do not influence the time, speed of construction and satisfaction with quality on such projects.

From Table 3 further results reveal that correlations exist between build type and performance factors of Labour-only procurement. It is shown that build type demonstrate negative relationships with unit cost, pre-construction time, build time, total time and time overrun it shows positive relationships speed, satisfaction on quality, project use to date and cost overrun. None of these relationships are significant hence the null hypothesis is accepted. Irrespective of the build type constructed in Labour-only projects the performance of the method is not influenced by these types. Table 3 also indicates results of correlations between final contract sum and performance factors of Labour-only procurement. It shows that pre-construction time, build time, total time, project use satisfaction and time overrun demonstrate negative correlations with final contract sum. However, unit cost, speed, satisfaction with quality on project and cost overrun show some positive relationships with final contract sum. 
None of these correlations are significant and hence the null hypothesis is accepted. Final contract sum is not influenced by performance factors of Labour-only procurement.

Table 3 Correlations of Contractual procedure, Designer's experience, Build type and final contract sum and performance factors of Labour-only procurement

\begin{tabular}{lllllllllll}
\hline Variable & $\begin{array}{l}\text { Unit } \\
\text { cost }\end{array}$ & $\begin{array}{l}\text { Pre- } \\
\text { const. } \\
\text { time }\end{array}$ & $\begin{array}{l}\text { Build } \\
\text { time }\end{array}$ & $\begin{array}{l}\text { Total } \\
\text { time }\end{array}$ & Speed & $\begin{array}{l}\text { Qualty } \\
\text { satisfa }\end{array}$ & $\begin{array}{l}\text { Proj. } \\
\text { use } \\
\text { satis }\end{array}$ & $\begin{array}{l}\text { Cost } \\
\text { Over } \\
\text { Run }\end{array}$ & $\begin{array}{l}\text { Time } \\
\text { Over } \\
\text { Run }\end{array}$ \\
\hline $\begin{array}{l}\text { Contractual } \\
\text { procedure }\end{array}$ & 0.1998 & 0.1487 & -0.2237 & 0.0429 & 0.1088 & -0.3025 & 0.1108 & -0.1108 & -0.4103 \\
$\begin{array}{l}\text { Designer's } \\
\text { experience }\end{array}$ & 0.4030 & -0.1150 & -0.0843 & -0.0898 & -0.2632 & -0.2978 & 0.1090 & 0.0682 & -0.0950 \\
$\begin{array}{l}\text { Build Type } \\
\text { Fuid }\end{array}$ & -0.1210 & -0.1553 & -0.2476 & -0.1945 & 0.1455 & 0.2218 & 0.2504 & 0.2292 & -0.0411 \\
$\begin{array}{l}\text { Final } \\
\text { contract sum }\end{array}$ & 0.2870 & -0.0377 & -0.0703 & -0.1407 & 0.1112 & 0.1252 & -0.3538 & 0.1516 & -0.1240 \\
\hline
\end{tabular}

Relationship between Contractual procedures, Designer's experience, building type, Final contract sum and Performance factors of Traditional procurement

Table 4 reveals that contractual procedure demonstrates some negative relationships with unit cost, pre-construction time, build time, total time, speed, cost and time overruns. It shows no relationships with satisfaction with project use and quality satisfaction on the project. None of these correlations are significant and hence the null hypothesis is accepted. This implies that contractual procedures show no association with performance factors of Traditional procurement. Irrespective of the methods used in selecting the tender the performance of Traditional procurement is not strongly influenced by the contractual procedure used for it. Results from Table 4 indicate that Designer's experience show positive correlations with all the performance factors of Traditional procurement but none of these correlations are significant.

The null hypothesis is hence accepted. It also implies that there is no strong association between Designer's experience and performance of Traditional procurement. Designer's experience does not improve performance of Traditional method. In Table 4 it indicates that build type has negative correlations with unit cost, speed of construction, cost and time overruns. It also demonstrates positive relationships with preconstruction time, build time, quality satisfaction on project and satisfaction with project use to date. However, build type demonstrates significant correlation with total time at 0.01 significance level. This involves accepting the alternative hypothesis which implies that a significant relationship exists between build type and total time of projects in Traditional procurement. Build types are strongly associated with total time spent on the project depending on complexity of the project. Results in Table 4 also show that final contract sum of the project has negative relationships with pre-construction time, total time, satisfaction with quality on project and satisfaction with use of project while it has positive relationships with unit cost, build time, speed of construction, cost and time overruns. For the significant correlations between final contract sum and unit cost as well as cost overrun at 0.001 significance levels involves accepting the alternative hypothesis. This shows that final contract sum has significant associations with unit cost and cost overrun. Both variables can be predictors of final contract sum in a traditional procurement method. 
Table 4 Correlation of contractual procedure, Designer's experience, Build type and final contract sum and performance factors of Traditional procurement

\begin{tabular}{llllllllll}
\hline Variable & $\begin{array}{l}\text { Unit } \\
\text { cost }\end{array}$ & $\begin{array}{l}\text { Pre- } \\
\text { const. } \\
\text { time }\end{array}$ & $\begin{array}{l}\text { Build } \\
\text { time }\end{array}$ & $\begin{array}{l}\text { Total } \\
\text { time }\end{array}$ & Speed & $\begin{array}{l}\text { Qualty } \\
\text { satis }\end{array}$ & $\begin{array}{l}\text { Proj. } \\
\text { use } \\
\text { Satis }\end{array}$ & $\begin{array}{l}\text { Cost } \\
\text { Over } \\
\text { Run }\end{array}$ & $\begin{array}{l}\text { Time } \\
\text { Over } \\
\text { Run }\end{array}$ \\
\hline $\begin{array}{l}\text { Contractual } \\
\text { procedure }\end{array}$ & -0.2081 & -0.2190 & -0.0514 & -0.1825 & -0.1732 & 0.0000 & 0.0000 & -0.0225 & 0.0576 \\
$\begin{array}{l}\text { Designer's } \\
\text { experience }\end{array}$ & 0.3630 & 0.0671 & 0.1290 & 0.8500 & 0.3500 & 0.2700 & 0.1540 & 0.0143 & 0.0356 \\
$\begin{array}{l}\text { Build Type } \\
\text { Final }\end{array}$ & -0.1850 & 0.5130 & 0.2640 & $0.5170^{*}$ & -0.0040 & 0.1016 & 0.3786 & -01040 & -0.0900 \\
contract sum & $0.8030^{*}$ & -0.1098 & 0.0545 & -0.1060 & 0.1436 & -0.2387 & -0.0110 & $0.8139^{*}$ & 0.3370 \\
\hline
\end{tabular}

\section{Conclusion}

In view of the findings of this study the following conclusions are deduced from the study: Procurement challenges in Labour-only projects seriously affect the unit cost of such projects. If procurement problems are pronounced in a Labouronly project it may be very expensive to achieve. Procurement challenges in Traditional projects also strongly influence its unit cost, build time and total time of the projects and hence it may also be expensive to build Traditional projects if procurement problems are also pronounced. In Labour-only projects the contractual procedures used, designer's experience, building type as well as final contract sum do not influence the performance of this method. Irrespective of contractual procedures in use in Labour-only method, experiences of the designers and the type of building projects the performance of the method is unaffected. The performance of Traditional procurement does not also depend on both the contractual procedures used and on designer's experience. Building type influences the performance of Traditional projects in terms of its total time while final contract sum of Traditional projects influences its performance in terms of unit cost and cost overrun. This study recommends the use of both methods to clients and consultants and when both methods are employed for projects, consultants and project executors should manage well all the procurement challenges encountered on such projects as to avoid cost escalations on these projects. For better performance of both methods in construction projects unit cost must be kept minimal while cost and time overruns must be highly reduced.

\section{References}

Abdolalipour, A. Shafiee, M and Rezaiee, Z. (2011), Designing a Balance Scorecard model for Procurement Performance Assessment in IOTC using TOPSIS in information and Financial Engineering 2011 proceedings of $3^{\text {rd }}$ International Conference in Singapore 2011, IACSIT Press, Singapore, 186-189.

Alarcon, L.F. and Ashley, D. B. (1996), Modeling Project Performance for Decision Making. Journal of Construction Engineering and Management, 265273.

Alarcon, L.F. and Serpell, A. (2004), Performance

Measuring Benchmarking and Modeling of

Construction Projects. Retrieved on $17^{\text {th }}$ August

2012 from <

file://D1/Diversos/Performance\%20measuring $\% 20 \mathrm{~b}$ $\% 20$ modelling $\% 20 \mathrm{of} \% 20$ construction $\% 20$ projects.h $\underline{\mathrm{tm}}$

Babatunde, S.O; Opawole, A. and Ujaddingbe, I.C. (2010), An Appraisal of Project Methods in the Nigerian Construction Industry. Civil Engineering Dimension, 12(1), 1-7.

Dada, M.O. (2012), A second look: Stakeholders' Perceptions of Some Issues in Design Bid-Build Procurement Practice in Nigeria. Journal of Sustainable Development, 5(1), 55-63.

Holt, R. and Graves, A. (2001), Benchmarking UK

Government Procurement Performance in Construction Projects. Measuring Business Excellence, 5(4),13-21.

Ibiyemi A.O., Adenuga A.O. and Odusami K.T. (2008), Comparative Analysis of Design and Build and the Traditional Procurement methods in Lagos, Nigeria. Journal of Construction, 2(2), 2-6.

McDermott, P. (1999), Strategic and Emergent Issues in Construction Procurement, in Rowlinson. 
S. and McDennott, P. (Eds.). Procurement Systems: A Guide to Best Practice in Construction. E \& PN Spon Publishers, London. 5-26.

Naoum, S.G (1991), Procurement and Project Performance: A Comparisons of Management and Traditional Contracting, The Chartered Institute of Building, Occasional Paper No. 115.

Naoum, S.G. and Langford, D.A. (1987), Management Contracting, in Lansey and Harlow, P.(Eds.), Managing Construction Worldwide, 1(1), 92-94.

Ogunsanmi, O.E. Iyagba, R.O.A and Omirin. M.M. (2001), A Comparative Study of the Performance of Traditional and Labour-only Procurement in some selected states of Nigeria. An unpublished $\mathrm{PhD}$ Thesis of Department of Building, University of Lagos. Lagos.

Ogunsanmi, O.E. Iyagba, R.O.A and Omirin, M.M. (2003), A Comparative study of the Performance of Traditional and Labour-Only Procurement in Nigeria. Journal of the Nigeria Institute of Building, $12-27$.
Ojo, S. O. (2009), Benchmarking the Performance of Construction Procurement Methods against Selection criteria in Nigeria. Civil Engineering Dimension, 11(2), 106-112.

Pinto, J. K. and Slevin, D. P. (1988), Project Success: Definitions and Management Techniques. Project Management Journal, XIX, ( 1), 67-71.

Public Procurement Audit Seminar, (2010). Procurement Performance Model. Retrieved from < http://www.tcontas.pt/pt/eventos/public_procuremen ts/docs/7.pdf

Rowlinson, S.M. and Newcombe, R. (1986), The Influence of Procurement form on Project

Performance, in Advancing Building Technology, Proceedings of CIB 86 Conference, U.S.A. pp. 3617-3624.

Samatania Konsult Limited, (2012), Labour-Only contract. Retrieved on 22 ${ }^{\text {nd }}$ January, 2012 from < http://www.samataniakonsultltd.com/our_services/la bour-onlycontract. 